\title{
AN ANALYSIS OF THE AGRICULTURAL ENTREPRENEURSHIP OF BROILER FARMERS IN OYO STATE, NIGERIA.
}

\author{
By \\ Rahji M.A.Y. ${ }^{1}$ Aiyelari T.E. ${ }^{2}$ Ilemobayo 0.0. ${ }^{1}$ and Nasiru M.O. ${ }^{1}$ \\ 'Dept. of Agricultural Economics, University of Ibadan, Nigeria. \\ ${ }^{2}$ General Studies Department, The Polytechnic, Ibadan, Nigeria
}

\begin{abstract}
The study examined the agricultural entrepreneurship of broiler farmers in Oyo state, Nigeria. Cobb Douglas stochastic and Cobb Douglas production functions were used in analyzing the data. Evidence from the stochastic function showed that the average entrepreneurial efficiency of the farmers was $89.2 \%$. About $53.6 \%$ of the farmers realized the mean level of efficiency. All the inputs were identified as significant factors in broiler production in the area. The result however also revealed negative significant response of broiler to labor. The result of the Cobb Douglas function indicated that the average prudent entrepreneurial efficiency of the farmers was $70.6 \%$. About $51.8 \%$ of the farmers attained more than the mean level of prudent entrepreneurial efficiency. These results implied that $11 \%$ and $29 \%$ of the farmers operated below their entrepreneurial and prudent entrepreneurial mean levels of efficiency respectively. The average managerial efficiency of the farmers was $72.4 \%$. About $64.3 \%$ of the farmers achieved the mean level of efficiency. Hence, $35.7 \%$ of the farmers operated below the mean managerial efficiency level. To improve entrepreneurial efficiency of the farmers, biological, chemical and mechanical technologies are recommended. In order to improve their managerial efficiency, policies that will improve the conditions in the inputs and output markets in terms of favourable prices to poultry farmers are required.
\end{abstract}

Keywords: Agricultural entrepreneurship, entrepreneurial efficiency, managerial efficiency prudent entrepreneurial efficiency, poultry farms, Oyo State, Nigeria. 


\section{Introduction}

The importance of food in the socio-economic development of any country cannot be overemphasized. Increased domestic food supply has been the major food policy objective of successive Nigerian Governments since the 1970 s. Such policy objective has been translated into many agricultural programmes and projects (see Idachaba, 2000). The emphasis on increased domestic food production capability can be justified in view of the poor performance of the food sub-sector of the Nigerian economy. The consequences of food demand supply gap are declining per capita production, high and rising food prices, increasing food import and a growing deterioration in the nutritional status of the average Nigerian (Falusi, 1995).

It is well-known that Nigeria's per capita intake of high quality animal protein is too low (Idusogie 1971; Olayide et al, 1972; Oyenuga, 1974; FAO, 1990). The health hazards of protein malnutrition have been well documented (FAO, 1965). According to Awosanmi, (1999); there is an increasing evidence of high infant mortality, low resistance to diseases, poor growth and development, mental retardation which result from inadequate protein in the diets of most Nigerian. According to FAO (1990), the diets of the people of the tropical zone and Nigeria (Tewe, 1993) are usually protein poor.

Apart from fishes, other sources of animal protein in Nigeria are cattle, poultry, piggery, sheep and goats. Hence, livestock industry of which poultry is a subset provides protein for the populace (Okubanjo and Adeneye, 1993). However, cattle, sheep and goats are poor candidates for rapid short-term increases in number. This is due to their low fecundity, long gestation and long generation interval. Very rapid increases can be achieved with respect to piggery and poultry within a short-time (Famoyin, 2000). Unlike pork that has no national spread due to religious beliefs, there are virtually no taboos that hinder the consumption of poultry meat or eggs (Ikeobi et al, 1999). Hence, poultry production has long been recognized as one of the quickest ways of rapid increase in protein supply in the short-run. The need to meet animal protein requirements from domestic sources demands intensification of production of meat and eggs, derived from prolific animals like poultry birds. Poultry has a shorter life-cycle and is much more prolific than larger livestock.

\section{Problem Statement}

A poultry farm is conceived as a technical unit of production under the control of a farmer who plays the dual role of the entrepreneur and the manager. But there is no explicit treatment of entrepreneurs or agricultural entrepreneurship in the theory of the farm-firm. However, entrepreneurship has been analyzed extensively in the context of industrial development in the literature. Industrial entrepreneurship can be transferred from one firm to another without much loss of entrepreneurial talents. Agricultural entrepreneurship is not transferable as it is farmspecific, location-specific and product-specific. There is thus the research need to analyze this concept in terms of the agricultural industry especially the poultry sector so as to close the gap existing in the literature on it. More so, the farm and farmer can be conceptualized as agricultural enterprise and agricultural entrepreneur respectively. 
Poultry farming units are the most common type of livestock production in Nigeria, (Famoyin, 2000). Before now, most of the poultry raised in the country was from the indigenous breeds. In recent years, commercial poultry farms using modern techniques and inputs such as improved breeds, better feeding methods and management practices have been established (Sonaiya, 1990). The poultry industry in Nigeria suffered from being largely import dependent (Adegbola, 1990). As a result of this, it was believed that the rate of expansion of this sub sector of the economy had been substantially reduced (Afolami, 1998). This was due to, among other factors, high feed cost; arising largely from increasing prices of ingredients, poor quality food and inefficiencies, in production and distribution (Adekojo, 2000).

The success of a poultry enterprise, irrespective of the size, largely depends on the kind of care and attention the flock receives (Alaka, 2000). This is reflected in the choice of birds, the choice of feed materials and the operational diseases control programmes of the enterprise. These factors inter-play to determine the total well-being or health status of the flock and the enterprise. It has long been established that profitability in the poultry industry depends largely on the biological efficiency of the birds, efficiency of feed consumption and viability. The economic efficiency of chicken meat production depends on the growth rate of the birds as well as the feeding cost and finishing time. Efficiency measurement has received considerable attention from both theoretical and applied economist (Bravo-Ureta and Rieger, 1991). Little of this research effort has been directed to the poultry industry and to the relative importance of the various components of poultry firms' efficiency.

Over the years, a series of methods has been developed to determine the technical efficiency of production units (Apezteguia and Garate, 1997). More so, measuring efficiency is important in the use of scarce resources in production. This is because it is a first step in a process that might lead to substantial resource savings (Bravo Ureta and Rieger, 1991). These resource savings have important implications for both policy formulation and firm management. This study contributes to the literature on firm level agricultural entrepreneurship measurement by applying the stochastic formulation, resource-use efficiency condition and /or profit maximization rule which yield efficiency measures that are free from distortions arising from statistical noise, inherent in deterministic models to the Nigerian poultry industry.

Despite the importance usually ascribed to entrepreneurship as a prime contributor to economic growth, no one has been able to measure the phenomenon empirically much less to evaluate analytically its influence on productivity growth, output per capita or any other measure of economic activity (Baumol, 1985). There is thus the research need for empirical quantification of farmers' entrepreneurial and managerial efficiency. The first will enable the identification of the output frontier. The second will enable the maximization of profit given the production frontier identified by the entrepreneur. Baumol(1985), stated that in the extensive discussions of the part played by entrepreneurship in an economy, the evidence that is offered frequently relates primarily to managerial efficiency.

The quantification of efficiency in agriculture has been extensive. (Battese, 1992; BravoUreta and Pinheiro, 1993; Coelli, 1995). Not much, efforts have been devoted to measuring agricultural entrepreneurship even though entrepreneurial efficiency is identically known as the 
technical efficiency of the farm in the stochastic frontier production function literature (Schmidt, 1986). There is the research need to explore this link as a way of bridging this apparent gap in the literature.

\section{Research Questions}

The research questions that prompted this investigation are: What are the factors affecting broiler production in the area of study? What is the average entrepreneurial efficiency level of broiler farmers as agricultural entrepreneurs? What is their prudent-entrepreneurial efficiency in terms of operating at the frontier production level or output? What is the average level of the farmers' managerial efficiency in terms of resource-use efficiency and/or profit maximization objective? These questions constitute the problem solving focus of this study.

\section{Objectives of the Study}

The main objective of this study is to model agricultural entrepreneurship of broiler farmers in Oyo state, Nigeria. Following from the research questions, the specific objectives of this study include: to identify the factors influencing broiler production in the area of study; measure the entrepreneurial efficiency of broiler farmers; determine the prudent entrepreneurial efficiency of broiler farmers and quantify the managerial efficiency of the farmers.

\section{Conceptual Framework}

The role of the agricultural entrepreneur is extremely critical in the economic results of agricultural enterprises (de Lauwere, 2005). His decision-making process and behaviour affect relevant factors such as the choice of the strategy required to keep up with demands (DouglasJose and Crumly,1993; Rougoor et al, 1998; Shrapnel and Davie,2001).

Entrepreneurship and management can be differentiated on the basis of the rents accruing to them. The quasi-rent or gross margin is the returns to a fixed input of production. This is measured as the difference between total revenue and total variable cost and is the opportunity cost of keeping the fixed factor in its current use. Quasi-rent is made up of transfer earning and pure economic profit. The part of the transfer earning accruing to management (fixed factor) is called the normal profit. The reward to entrepreneurship is known as pure economic profit. It is thus necessary to differentiate these aspects in the production process and quantify them. An agricultural entrepreneur is hereby conceptualized as one who operates on his "best technique" production function to obtain the maximum possible output which is feasible with current technology and his socioeconomic and physical environment (Schumpeter, 1967). This concept implies that an individual's entrepreneurial efficiency can be specified by his production function, which shows what he is capable of producing under given conditions (Friedman, 1967).

Schultz's (1964), "the poor but efficient farmer" hypothesis serves as the basis of conceptualizing the farmer as a manager. Farmers are thus good managers by their ability in efficiently allocating their resources. The role of the manager only comes in after the entrepreneur has identified his production technology and technical opportunities (Kirzner,1982).According to

\section{6}


Key and McBride (2003), managerial and entrepreneurial abilities/efficiencies are characteristics that could be correlated with farm productivity.

Leibenstein (1966), emphasized the role of the prudent entrepreneur as one who possesses both entrepreneurial and managerial abilities. Farms thus require the services of entrepreneurs so as to eliminate technical slack in order to operate on their production possibility frontier consistent with their resources (Leibenstein, 1973). Prudent entrepreneurship is defined as the product of entrepreneurial and managerial efficiencies while ability and efficiency are used interchangeably (Kalirajan and Shand,1994).

Entrepreneurial efficiency is an output-oriented efficiency measure obtained econometrically from the estimated Cobb Douglas function as technical efficiency. This follows the work of Kalirajan and Shand (1994). Output is treated frequently as a stochastic variable because of weather conditions, diseases and other exogenous random forces (Reinhard et al; 1999). It is assumed here that the decision variables are fixed in the short-run and that the production level follows a common and reasonable assumption when estimating production relationship in agriculture (Coelli, 1995).

\section{Analytical Framework}

\section{The Frontier Output}

The stochastic frontier production function is specified as:

$$
\begin{aligned}
& Q i=f\left(X_{1}, X_{2}, X_{3}, X_{4}\right) e^{V_{i}+U i} \\
& e^{e_{i+U i}}=e^{V_{i}} e^{U i}
\end{aligned}
$$

Where $\mathrm{Qi}=$ Output of broiler in $\mathrm{kg}, \mathrm{X}_{1}=$ labour inputs in hours; $\mathrm{X}_{2}=$ cost of capital and others is measured as the depreciation on capital assets and the interest on loans/credit. These are easily measured in value than in physical terms; $X_{3}=$ cost of agrochemicals. Cost is used here because it is more amenable to the theory of production and economic interpretation than litres, the unit of measurement for agrochemicals; and, $X_{4}=$ number of broiler birds is used as a proxy for farm size. Different birds such as Abor acre, Hybro, Ross and Anak are used in production in that order. The emphasis in this study is on the weight of the birds given the same inputs. This accounts for why the output is measured in kilograms.

\section{Omitted Variables in the Analysis}

The influence of omitted variables in the analysis can be classified into two groups.

The influence of the first group represents the socio-economic factors which affects output indirectly by influencing the entrepreneurial ability of the farmers in his entrepreneurial and managerial roles. This can be examined under $e^{\mathrm{ui}}$. This influence is known to be farm and product specific and is not normally distributed across the farmers. It is assumed that the farmers' entrepreneurial ability behaves in a similar manner. This implies that he either operates on or below 
the frontier.

$e^{\mathrm{Ui}}$ refers to the farm specific entrepreneurial behaviour of the farmer and $\mathrm{Ui}$ is nonpositive. It is either zero or negative ( $\mathrm{Ui}=0)$. If $\mathrm{Ui}$ is negative $(\mathrm{Ui}<0)$, he is operating below the frontier and is output. This implies that he is not fully realizing his entrepreneurial capacity. If $\mathrm{Ui}=0$, the ith farmer is operating on the frontier and is fully realizing his entrepreneurial capacities. His frontier output function is given by:

$$
\mathrm{Qi}^{*}=\mathrm{f}\left(\mathrm{X}_{1}, \mathrm{X}_{2}, \mathrm{X}_{3}, \mathrm{X}_{4}\right) \mathrm{e}^{\mathrm{Vi}}
$$

The farmer's entrepreneurial efficiency is conceived as a neutral transformer of the stochastic output frontier. The influence of the second group involves $e^{v_{i}}$ which is a random disturbance. It captures the influence of the less important left-out variables if any. Vi is either more than, less than or equal to zero. It indicates that the outer bound output frontier varies from farm to farm and for the same farm over time (Kalirajan and Shand, 1994). It represents the statistical noise outside the control of the farmer (Apezteguia and Garate, 1997).

The farm-specific entrepreneurial efficiency (EE) of the ith farmer (Kalirajan and Shand, 1994) is defined as:

$$
E E=\frac{(\underline{Q i} / U i)}{\left(Q_{i}^{*} / U i=0\right)}
$$

The entrepreneurial efficiency as defined is thus identically equivalent to the technical efficiency of the farm. (Schmidt,1986).

\section{The Optimal Output}

The theory of the firm states that optimal output is obtained at the point of tangency of the production frontier and the farm-specific price-line. Optimal output is obtained by simultaneously estimating the production frontier in conjunction with the marginal productivity conditions of the variable inputs used in production. The production frontier can be represented by

Qi $=f\left(X_{1}, X_{2}, X_{3}, X_{4}\right) e^{E}$

$E$ is the error term. All other variables are as already defined. The marginal productivity conditions of the inputs are represented by

$$
\mathrm{Ci}=\mathrm{Di}+\Sigma \mathrm{Dij} \ln \mathrm{Xj}+\mathrm{Wi} ; \mathrm{j}, \mathrm{i}=1,2,3,4 \text {. }
$$

$\mathrm{Ci}$ is the share of the total variable cost $(\mathrm{Pxi} \mathrm{Xi})$ of the ith input in the total revenue $\left(\mathrm{P}_{\mathrm{Q}} \mathrm{Q}\right)$. Wi is the sum of the allocative error and statistical random error. The resultant optimal output function is designated as ${ }^{\wedge} Q(Q$ hat $)$.

Q $Q i=f\left(X_{i}^{*}, X_{2}^{*}, X_{3}^{*}, X_{4}^{*}\right)$

Where $X_{i}^{*}$ s are the profit-maximizing optimal inputs. 


\section{Issues in Frontier Output and Resource use Efficiency}

Three issues arise when examining the frontier output in relation to resource use efficiency in production. Is the frontier output consistent with the farm's resource-use efficiency? Is the frontier output the same as the optimal output obtained when VMP $=$ MFC or MR $=M C$ ? Can there be an optimal frontier output if the residuals of the optimal output function do not obey the rule ei $=0$ such that the intercept requires adjustment? These questions require empirical quantification.

\section{Optimal Frontier Output}

The constant term of the optimal output equation (6) is expected to be non-consistent. In that case, the equation requires to be converted to a frontier function (see Bravo-Ureta and Rieger, 1990) using the approach by Greene (1980). This is done by adding the maximum positive residual (RE) from equation (6) to the constant term but subtracted from each residual. The residuals thus become non-positive (ei $=0)$ with at least one being zero. The optimal frontier output is designated as -(Qibar). The farmer's prudent entrepreneurial efficiency (PE) is defined as

$P E^{Q}=\underline{Q} / U i$

$$
\mathrm{Qi} / \mathrm{Ui}=0 ; \mathrm{VMP}=\mathrm{MFC} \quad ; \quad \mathrm{PE}<1
$$

$\mathrm{PE}$ can be decomposed into entrepreneurial efficiency (EE) and managerial efficiency (ME) as:

$$
\begin{aligned}
\frac{Q i}{Q i} & =\frac{Q i}{Q i^{*}} \frac{Q i^{*}}{Q i b a r} \\
& =Q i / Q i^{*} \times Q i^{*} / \bar{Q}
\end{aligned}
$$

ME is the ratio of the frontier and optimal frontier outputs $\left(Q^{*} i\right) / \bar{Q}$ (Qibar).

\section{Area of study}

\section{Methodology}

The area of study is Ibadan zone of Oyo State, Nigeria. It is made up of eleven Local Government Areas (LGAs). The five LGA's, making up the former Ibadan Municipal Government Area, are however excluded from the analysis. These are Ibadan Southwest, Ibadan, Northeast, Ibadan South, Ibadan Northwest and Ibadan North. These are classified as strictly urban LGAs. According to Ricardo (1817) an urban economy is that which is industrialized, commercialized and provides adequate infrastructural facilities (physical, social and institutional). Such an area must have at least 10 out of the 15 other listed characteristics. The characteristics are (1) electricity, (2) pipe-borne water, (3) tarred roads, (4) industries, (5) federal / state government offices, (6) telephone network, (7) banking services, (8) commercial centres, (9) post offices, (10) private I public hospitals, (11) post-primary institutions, (12) public or private intra-town transport services, (13) courts of magisterial status and above, (14) recreation clubs / facilities (hotels, cinema houses, 
amusement parks, zoos) and (15) police stations (Falusi, 1995). The other six LGAs are Oluyole, Ona-ara, Egbeda, Lagelu, Akinyele and Iddo. They are denoted as strictly rural LGAs. The latter LGAs are used as the sampling frames for the current study. This is because most agricultural activities (livestock, fisheries and crops) are carried out within the peri-urban fringes of Ibadan due to land scarcity. Ibadan a densely populated city has a population of about 2 million inhabitants (Census, 1991). The high population translates to ready market for most commodities.

\section{Method of Data Collection}

A simple random sampling procedure was used in selecting the sample needed for this study. The six LGAs classified as strictly rural were used for this exercise. In each LGA, a random sample of 10 broiler firms was taken using the list of firms provided by the Poultry Association of Nigeria. The Random Number Process was applied. This gave a sample size of 60 firms. The incompleteness of information provided by some firms informed the decision to use 56 farms in the subsequent analysis. This sample size that is greater than 30 was deemed large enough for the relevant analysis Data were collected on input output relationships of the firms, costs of inputs, prices of output, labour utilization, veterinary services, drugs and other relevant information pertaining to the operation of the firms.

\section{Frontier Output Model}

\section{Method of Data Analysis}

ACobb Douglas production function is assumed to characterize the farmers' production technology in all cases following Kalirajan and Shand, (1994) and Parikh and Shah, (1994). The Cobb Douglas stochastic frontier function used to obtain the frontier output is written as:

$\ln Q i=\beta_{0}+\beta_{1} \ln X_{i}+\beta_{2} \ln X_{2}+\beta_{3} \ln X_{3}+\beta_{4} \ln X_{4}+V i U i$

Where Qi = Output of broilers $(\mathrm{kg}), \mathrm{X}_{1}=$ labour inputs ( hours); $\mathrm{X}_{2}=$ cost of capital and others; $\mathrm{X}_{3}=$ cost of agrochemicals and $X_{4}=$ number of broiler birds, a proxy for farm size.

\section{Optimal Output Model}

The simultaneous equation model is made up of a Cobb Douglas production function and four marginal productivity condition equations.

$\ln Q i=b_{0}+b_{1} \ln X_{i}+b_{2} \ln X_{2}+b_{3} \ln X_{3}+b_{4} \ln X_{4}+e i$

$C_{1}=D_{1}+D_{11} \ln X_{1}+D_{12} \ln X_{2}+D_{13} \ln X_{3}+D_{14} \ln X_{4}+W_{1} \ldots$ (11)

$C_{2}=D_{2}+D_{21} \ln X_{1}+D_{22} \ln X_{2}+D_{23} \ln X_{3}+D_{24} \ln X_{4}+W_{2}$

$C_{3}=D_{3}+D_{31} \ln X_{1}+D_{32} \ln X_{2}+D_{33} \ln X_{3}+D_{34} \ln X_{4}+W_{3}$

$C_{4}=D_{4}+D_{41} \ln X_{1}+D_{42} \ln X_{2}+D_{43} \ln X_{3}+D_{44} \ln X_{4}+W_{4}$ 
Wi is the sum of the allocative error and statistical random error. Equations 10 and 11 are estimated simultaneously to obtain the optimal output. This is then used to generate the optimal frontier output as already discussed.

This model is a special case as identical set of explanatory variables is used in all the equations (Mahdavi, 2004). The SURE and OLS methods as a result will yield identical parameter estimates for the equations. STATA 10.0 was used in estimating the models.

\section{Results and Discussion}

Table 1 contains the results of the estimated Cobb Douglas stochastic frontier production function.

Table 1: Results of the estimated Stochastic Frontier Production Function for Broiler Farmers

\begin{tabular}{|l|l|l|}
\hline Variables & Parameters & t-values \\
\hline $\operatorname{Ln} X_{1}$ & $-0.1745^{*}$ & 1.8352 \\
\hline $\operatorname{Ln} X_{2}$ & $0.4647^{* *}$ & 2.5236 \\
\hline $\operatorname{Ln} X_{4}$ & $0.4076^{* *}$ & 3.3245 \\
\hline $\operatorname{LnX} 4$ & $0.5444^{* *}$ & 6.7269 \\
\hline Constant $(K)$ & $0.2203^{*}$ & 1.6984 \\
\hline
\end{tabular}

Source: Data Analysis, 2011. $\quad{ }^{* * *}$ significant at $1 \% \quad{ }^{* *}$ significant at $5 \% \quad{ }^{*}$ significant at $1 \%$

$\lambda=2.8783$

$\gamma=0.8923$

óu ${ }^{2}=0.1673$, óu $=0.40901$

Óv $v^{2}=0.0202, \quad$ Óv $=0.1421$

$\dot{o}^{2}=0.1875, \quad \dot{0}=0.4330$

log likelihood $=-125.9716 \quad N=56$

The Lambda $(\lambda)$ with a value of 2.8783 which is greater than one signifies a good fit for the estimated model. It also indicates the appropriateness of the required distributional assumptions for the decomposed error term. The results showed that all of the inputs are significant factors affecting broiler output. These are significant at different levels of significance. The result also revealed positive significant response of the broilers to the inputs except labour that is negative. The implication of this finding is that increases in the positive factors will result in increased output. Increase in the negatively signed input will lead to a decrease in the output. Hence, the factors affecting broiler production are thus identified and the first objective is met. 
Table 2: The estimated Production Function from the Simultaneous model

\begin{tabular}{|l|l|l|}
\hline Variables & Parameters & t-values \\
\hline $\operatorname{Ln} X_{1}$ & $-0.1745^{\star}$ & 1.8352 \\
\hline $\operatorname{Ln} X_{2}$ & $0.4647^{\star *}$ & 2.5236 \\
\hline $\operatorname{Ln} X_{4}$ & $0.4076^{* *}$ & 3.3245 \\
\hline $\operatorname{LnX} 4$ & $0.5444^{* \star *}$ & 6.7269 \\
\hline Constant $(K)$ & $0.2193^{*}$ & 1.9543 \\
\hline
\end{tabular}

Source: Data Analysis, 2011. $\quad{ }^{* * *}$ significant at $1 \% \quad{ }^{* *}$ significant at $5 \% \quad{ }^{*}$ significant at $1 \%$ $\mathrm{R}^{2}=0.9263$

$F=160.2486$

$N=56$

$\mathrm{N} / \mathrm{B}$ : Results of the marginal productivity conditions are not but are available on request.

Table 2 contains the results of the estimated Cobb Douglas production function from the simultaneous equation model. The $R^{2}$ of 0.9263 signifies a good fit for the estimated equation. The result of the stochastic frontier Cobb Douglas function is similar to that of the simultaneous model's Cobb Douglas function as expected (Mahdavi, 2004). The difference is in their intercepts. The intercept for the former is 0.2203 while that for the latter is 0.2193 . The results showed that all of the inputs are significant factors affecting broiler output. The result also revealed positive significant response of the broilers to the inputs except labour that is negative. The implication of this finding also is that increases in the positive factors will result in increased output. Increase in the negatively signed input will lead to a decrease in the output.

Table 3: The Optimal Frontier Production Function from the Simultaneous model.

\begin{tabular}{|l|l|l|}
\hline Variables & Parameters & t-values \\
\hline $\operatorname{Ln} X_{1}$ & $-0.1745^{\star}$ & 1.8352 \\
\hline $\operatorname{Ln} X_{2}$ & $0.4647^{* *}$ & 2.5236 \\
\hline $\operatorname{Ln} X_{4}$ & $0.4076^{* * *}$ & 3.3245 \\
\hline $\operatorname{LnX} 4$ & $0.5444^{* *}$ & 6.7269 \\
\hline Constant $(\mathrm{K}+\mathrm{RE})$ & $0.5628^{*}$ & 1.9543 \\
\hline
\end{tabular}

Source:DataAnalysis, 2011. $\quad{ }^{* * *}$ significant at $1 \% \quad{ }^{* *}$ significantat $5 \% \quad$ * significantat $1 \%$ $\mathrm{RE}=0.3435, \quad \mathrm{~K}=0.2193$.

$\mathrm{R}^{2}=0.9263$.

$\mathrm{F}=160.2486$.

$\mathrm{N}=56$. 
However, an examination of the residuals of the estimated equation from the simultaneous model indicated non-consistency as expected. This finding gave credence to the use of Greene's (1980) approach of Corrected Ordinary Least Squares (COLS) to obtain the optimal frontier output as already discussed under the analytical tool section. The result from the COLS is presented in Table 3 above. The results showed that all of the inputs are significant factors affecting broiler output. These are significant at different levels of significance. The result also revealed positive significant response of the broilers to the inputs except labour that is negative. The implication of this finding is that increases in the positive factors will result in increased output. Increase in the negatively signed input will lead to a decrease in the output. The results in Tables 2 and 3 thus helped in reinforcing the meeting of the first objective of this study.

Table 4 shows the frequency distribution of the entrepreneurial efficiency of the farmers. Average entrepreneurial efficiency of the farmers was $70.3 \%$. About $53.6 \%$ of the farmers realized the mean level of efficiency. In this way, the second objective is attained

Table 4: Frequency Distribution of Entrepreneurial Efficiency of the Farmers

\begin{tabular}{|l|l|l|}
\hline EE & No & $\%$ \\
\hline $0.51-0.55$ & 5 & 8.93 \\
\hline $0.56-0.60$ & 7 & 12.50 \\
\hline $0.61-0.65$ & 6 & 10.71 \\
\hline $0.66-0.70$ & 8 & 14.29 \\
\hline $0.71-0.75$ & 10 & 17.86 \\
\hline $0.76-0.80$ & 13 & 23.21 \\
\hline $0.81-0.85$ & 4 & 7.14 \\
\hline $0.86-0.90$ & 2 & 3.57 \\
\hline $0.91-0.95$ & 1 & 1.79 \\
\hline e0.96 & 0 & 0.00 \\
\hline Total & 56 & 100.00 \\
\hline
\end{tabular}

Source: Data Analysis, 2011.

Table 5 presents the frequency distribution of the prudent entrepreneurial efficiency of the farmers. The result indicated that the average prudent entrepreneurial efficiency was $70.6 \%$. About $51.8 \%$ of the farmers attained more than the mean level of prudent entrepreneurial efficiency. These results implied that $30 \%$ and $29 \%$ of the farmers operated below their entrepreneurial and prudent entrepreneurial mean levels of efficiency respectively and so the third objective is achieved. 
Table 5 :Frequency Distribution of Prudent Entrepreneurial Efficiency of the Farmers

\begin{tabular}{|l|l|l|}
\hline PEE & No & $\%$ \\
\hline $0.51-0.55$ & 3 & 5.36 \\
\hline $0.56-0.60$ & 6 & 10.71 \\
\hline $0.61-0.65$ & 8 & 14.29 \\
\hline $0.66-0.70$ & 10 & 17.86 \\
\hline $0.71-0.75$ & 10 & 17.86 \\
\hline $0.76-0.80$ & 14 & 25.00 \\
\hline $0.81-0.85$ & 1 & 1.79 \\
\hline $0.86-0.90$ & 3 & 5.36 \\
\hline $0.91-0.95$ & 1 & 1.79 \\
\hline e0.96 & 0 & 0.00 \\
\hline Total & 56 & 100.00 \\
\hline & &
\end{tabular}

Table 6 shows the frequency distribution of managerial efficiency of the farmers. The average managerial efficiency stood at $72.4 \%$. About $64.3 \%$ of the farmers achieved the mean level of efficiency. Hence, $27.6 \%$ of the farmers operated below the mean managerial efficiency level. The fourth objective is thus met. These farmers are thus found to be inefficient in their resource-use in poultry production. The implication of these results is that there is room to attain both frontiers with improvement in entrepreneurial and managerial skills of the farmers.

Table 6: Frequency Distribution of Managerial Efficiency of the Farmers

\begin{tabular}{|l|l|l|}
\hline $\mathrm{ME}$ & No & $\%$ \\
\hline $0.51-0.55$ & 2 & 3.57 \\
\hline $0.56-0.60$ & 4 & 7.14 \\
\hline $0.61-0.65$ & 5 & 8.93 \\
\hline $0.66-0.70$ & 9 & 16.07 \\
\hline $0.71-0.75$ & 14 & 25.00 \\
\hline $0.76-0.80$ & 16 & 28.57 \\
\hline $0.81-0.85$ & 3 & 5.36 \\
\hline $0.86-0.90$ & 2 & 3.57 \\
\hline $0.91-0.95$ & 1 & 1.79 \\
\hline e0.96 & 0 & 0.00 \\
\hline Total & 56 & 100.00 \\
\hline
\end{tabular}

Source: Data Analysis, 2011. 


\section{Policy Issues}

There is the need for an upward shift in the production function of the farmers. By so doing, the inefficiency gap will be reduced or eliminated. Improved production technologies (biological and mechanical) can be the solutions to this problem. In the alternative, labour enhancing technologies or for efficiency improvement can be provided to ensure that the existing technologies are efficiently used and productivity growth is attained. In terms of managerial efficiency, the market conditions in the output and input markets need to be favourable to agricultural production.

In conclusion, it is the contention of this paper that if Entrepreneurial Efficiency and Managerial Efficiency can be sufficiently improved, then Prudent efficiency will be much higher. Output will increase and the farmers will be more efficient. The government must therefore ensure that the right conditions exist in the markets.

\section{References}

Adegbola, T.A. (1989) "A Study of Commercial Poultry in Selected Farms in Abeokuta" Journal of Animal Production, 9(2):61 72.

Adekojo, A.Z (2000) "Economic Implication of Integrating Feed into Egg Production in "Ibadan" Unpublished M.Sc. Thesis. Department of Agricultural Economics, University of Ibadan, Nigeria. Pp 85

Afolami, C.A and Afolami S.O (1998) "Implications of seasonal Price Patterns and Price Trends on Table Eggs, Layer Mash and Pullet day-old Chicks for Egg producers in Ogun State, Nigeria" Tropical Journal of Animal Sciences, Vol. 1 (2): 15-25

Alaka, 0.0. (2000) Small Holder Poultry Health Management Department of Vet. Pathology University of Ibadan, Nigeria. Pp 37

Apezteguia, B.I. and Garate, M.R. (1997) "Technical Efficiency in the Spanish Agrofood Industry" Agricultural Economics, 17:179-189.

Awosanmi, V.O. (1999) "Nigeria Needs to Recover from its present state of Poultry Production" Tropical Journal of Science, 2(3): 2126.

Baumol, W.J (1985). Business Behaviour Values and Growth. Harcourt and Brace Inc.Pp 258 
Battese, G. (1992). Frontier Production Functions and Technical Efficiency ; A Survey of Empirical Applications in Agricultural Economics. Agricultural Economics, 7: 185-208.

Bravo- Ureta, E. and L. Rieger (1991). Dairy Farm Efficiency Measurement using Stochastic Frontier and Neoclassical Duality. American Journal of Agricultural Economics, 73:421428.

Bravo-Ureta, E. and A. Pinheiro (1993). Efficiency Analysis of Developing Country - Agric ulture: A Review of the Frontier Function Literature. Agric. Resource Economics Review, 22:88-101

Coelli, T. (1995). Recent Developments in Frontier Modelling and Efficiency Measurement. Australian Journal ofAgricultural Economics, 39(3): 219-245.

de Lauwere, C.C. (2005) "The Role of Agricultural Entrepreneurship in Dutch Agriculture of Today" Agricultural Economics, 33:229-238.

Douglas-Jose, H and Crumly, J. (1993) "Psychological Type of Farm/Ranch Operators: Relationship to Financial Measures" Review of Agricultural Economics, 15(1): 121-132.

Falusi, A.O. (1995) "An Overview of Nigeria's Rural Economy: Status, Problems and Potentials" NCEMAWorkshop PaperAugust, 20 25, 1995 Ibadan. Pp 18

Famoyin, J. (2000) Poultry Farming Project:X Tower Veterinary Konsult, Ibadan Nigeria. Pp 36

FAO (1965) Protein Requirements FAO Nutrition Meeting Report, Series No. 37 Rome.Pp 124

FAO (1990) Food Composition Tables for Use in Africa: Rome. Pp 130.

Friedman, M. (1967) Price Theory: A Provisional Text. Aldine Publishing Co., Chicago, U.S.A. Pp.302

Greene, W. (1980). Maximum Likelihood Estimation of Econometric Frontier Functions. Journal of Econometrics, 13:27-56. 
Idachaba, F.S. (2000) Tropical Issues in Nigerian Agriculture Department of Agricultural Economics, University of Ibadan, Nigeria. Pp 24

Idusogie, E.0, (1971) "The Nutritional Requirements of the Nigerian Population" African Journal of Medical Sciences, 3(1);34- 48

Ikeobi, C; Higinus, C.N; Adenowo, J.A.; and Adebambo, O.A: (1999) "Egg Quality Characteristics from Local Poultry Species in Nigeria" Tropical Journal of Animal Sciences, 1(1): 3742.

Kalirajan, K.P. and Shand, R.T. (1994) "On modeling Agricultural Entrepreneurship" Indian Journal of Agricultural Economics, 49 (1):79-86.

Key, N. and McBride, W. (2003) "Production Contracts and Productivity in the U.S. Hog Section" American Journal of Agricultural Economics, 85(1):121-133.

Kirzner, I.M. (1982) Competition and Entrepreneurship. Chicago University Press, Chicago, U.S.A.Pp 254

Leibenstein, H. (1966) "Allocative Efficiency Vs 'X-Efficiency' American Economic Review, 56(3):392-415.

Leibenstein, H. (1973) "Competition and X-Efficiency: Reply" Journal of Political Economy 81:765-777.

Mahdavi, S. (2004) Shifts in the Composition of Government Spending in Response to External DebtBurdens. World Development, 32(7): 1139-1157.

Okubanjo, A.O. and Adeneye, J.A. (1993): Fundamentals of Agriculture. Publication of Faculty of Agriculture Unibadan (eds). Aiyelari, E.A; Lucas, E.O. Abatan, M.O. and Akinboade, O.A. Pp 304

Olayide, S.O.; Olatunbosun, D; Idusogie, E.O.; and Abiagom A.(1972) A Quantitative Analysis of Food Requirements: Supplies and Demands in Nigeria 1968 1985. Federal Department of Agriculture, Lagos. Pp 65 
Oyenuga, V.A. (1974) "The State of Nigerian Livestock in Meeting Requirements for Animal for products" Nigerian Journal of Animal Production, 1(1): 1-15.

Parikh, A. and Shah, K. (1994) "Measurement of Technical Efficiency in the North-West Frontier Province of Pakistan" Journal of Agricultural Economics, 45(1):132-138.

Ricardo, D. (1817) Principles of Political Economy as quoted in MacDonald, J .F. (2005). Fundamentals of Urban Economics. Lecture Notes http://www.2.sisu.edu/faculty/watsins/e166g.htm accessed 04/13/2005.

Rougoor, C.W; Trip, G; Huirne, R.B.M; Renkema, J.A. (1998) "How to define and study farmers' management capacity: Theory and use in Agricultural Economics" Agricultural Economics, 18:261-272.

Schmidt, P. (1986) “Frontier Production Functions" Econometric Reviews, 4: 289-328.

Schultz, T.W. (1964) Transforming Traditional Agriculture. Yale University Press, New Haven Connecticut, U.S.A.Pp 278

Schumpeter, J.A. (1967). The Theory of Economic Development. Harvard University Press, Cambridge, U.S.A.Pp 302

Shrapnel, M; and Davie, J. (2001) "The Influence of Personality in Determining Farmer Responsiveness to Risk" Journal of Agricultural and Education Extension, 7(3): 167-178.

Sonaiya, E.B (1990) Systems Approach to Rural Poultry Development. African Network on Rural Poultry Development, lle-Ife Nigeria. Pp 236

Tewe, 0.0. (1997) Sustainability and Development: Paradigms from Nigeria Livestock. Industry. An Inaugural Lecture, University of Ibadan, Ibadan 1997. Pp 65. 